\title{
Studies on spelling in the context of dyslexia: a literature review
}

Luciana Cidrim $^{(1)}$

Francisco Madeiro(1)

Universidade Católica de Pernambuco UNICAP, Recife, PE, Brasil.

Research support source: Coordenação de Aperfeiçoamento de Pessoal de Nível Superior (CAPES)

Conflict of interest: Nonexistent

Received on: July 06, 2017 Accepted on: October 06, 2017

\section{Mailing address:}

Luciana Cidrim Calado Meira

Rua Carlos Pereira Falcão 298 -

Boa Viagem

CEP: 51021-350 - Recife, Pernambuco, Brasil

E-mail: lucianacidrim@terra.com.br

\section{ABSTRACT}

This paper aimed at reviewing the literature related to national and international research on spelling difficulties by dyslexics and identifying the intervention approaches performed with regard to this topic. An integrative review of the literature was carried out in order to answer the question: considering the domain of the orthography, one of the challenges frequently faced by dyslexics, how are studies on the relationship between dyslexia and spelling characterized? The research was carried out in PubMed platform, Scopus database and Portal de Periódicos CAPES/MEC. To search the articles, the following descriptors were used: "dislexia" or "dyslexia" with the free terms "ortografia" or "spelling". One aspect should be highlighted: some works indicate that difficulties in the spelling performance by dyslexics are not exclusively due to phonological processing failures - they are also secondary to alterations in orthographic processing. A challenge faced by dyslexics is to retain phonological information to use in writing new orthographic forms. Researchers suggest that intervention strategies include phonological, orthographic and lexical activities. It is observed that few studies have analyzed the difficulties that dyslexics face when dealing with new words, as well as writing, correctly, frequently used words in their own language.

Keywords: Dyslexia; Handwriting; Learning 


\section{INTRODUCTION}

There is currently a constant concern from both medical and educational scope regarding difficulties on learning how to read and how to write.

Learning how to write is underpinned by a series of properties and aspects of the written form that are part of the orthographic system ${ }^{1-3}$. This type of learning incorporates how to differentiate the formation of letters, to develop phonological awareness, to establish quantitative correspondence, to identify the position of letters in a word, to understand that the same letter may represent different sounds, as well as to understand that the same sound can be represented by different letters. Therefore, writing orthographically is not an easy task ${ }^{3}$.

The orthographic knowledge refers to the understanding of how letters are combined to form words, being acquired through repeated exposure, acquisition of phonological awareness and knowledge of the rules for the formation of the orthographic mental lexicon ${ }^{3,4}$.

Spelling errors are part of the infant's learning process $^{1,3,5}$. Although kids progressively overcome those errors as they obtain deeper understanding of the features of the orthographic system they use to write, the persistence of errors and the kind of errors they make might indicate some learning disability ${ }^{3}$.

Dyslexia as a functional learning disability is a neurological disorder characterized by specific difficulties in the reading and writing skills, which are not secondary of cognitive alterations, neither lack of opportunity in formal education ${ }^{6}$.

Researchers point out that, regarding dyslexia, the major focus of most studies has been reading difficulties, and there is less research about the orthographic processing in dyslexic children ${ }^{2,3,5,7-9}$, although to correctly underline words be a challenge that might extend to adulthood ${ }^{10}$. Regarding learning problems, the investigation focus should not be limited to reading characteristics, it is necessary to understand the analysis of writing ${ }^{3,11}$.

The main goal of this study is to revise scientific literature that is related to research about spelling difficulties faced by dyslexic, as well as to identify approaches of interventions on the aforementioned theme.

\section{METHODS}

An integrative review of the literature based on national and international research was carried out to answer the following question: Considering the orthographic system skills one of the challenges most commonly faced by dyslexics, how are the studies about the relation between dyslexia and spelling characterized?

The research was carried out in PubMed platform, Scopus database and Portal de Periódicos CAPES/ MEC. To search the articles, Descriptors in Health Science (DeCS) and Medical Subject Headings (MESH) were used in combination: "dyslexia" or "dislexia" and the free terms "spelling" or "ortografia". Articles that were published within the last five years were selected through advanced search, excluding books. To search the combined terms, the option title/abstract was selected in the PubMed; title, abstract and keywords in the Scopus database and subject in the Portal de Periódicos CAPES/MEC.

The development of this article of literary review is part of a doctorate thesis, still under development, with the title "Dyslexic Sight Words (DSW) and Speech Therapy Intervention in Dyslexic children", from the Graduate program of Sciences of Language at Universidade Católica de Pernambuco - UNICAP/PE.

In this research, complete original articles or review articles published in the last five years in Portuguese or English were included, which answered the guiding question and which addressed the theme established by the descriptors and free terms.

Articles that repeated were excluded. The following exclusions were also carried out: review articles about the symptoms of dyslexia; research about orthography with non-dyslexic; neuroimaging study with dyslexics; articles about reading and dyslexia, specifically; research with dyslexics about spelling regarding the sounding out of words, instead of writing down words; articles about the executive and neuropsychological functions of dyslexia; generic studies about dyslexia, and articles about "acquired dyslexia" due to vascular cerebral accident.

\section{LITERATURE REVIEW}

The analysis of the data was divided into stages. Firstly, all articles obtained through the combination of descriptors and terms "dislexia" AND "ortografia" AND "dyslexia" and "spelling" were identified, and all abstracts were read. Afterwards, the first part of exclusion, which followed the benchmarks of this research, was realized.

All remaining articles were separated to be read in full and the repeated articles were removed. After thorough reading, other articles were eliminated 
because they did not meet the criterion stablished initially (Figure 1).

The selected articles were organized from the earliest to the latest according to the date of publication and, after reading each one, the following information was declared: author(s) and year of publication, constitution of sample, and description of study (Figure 2).

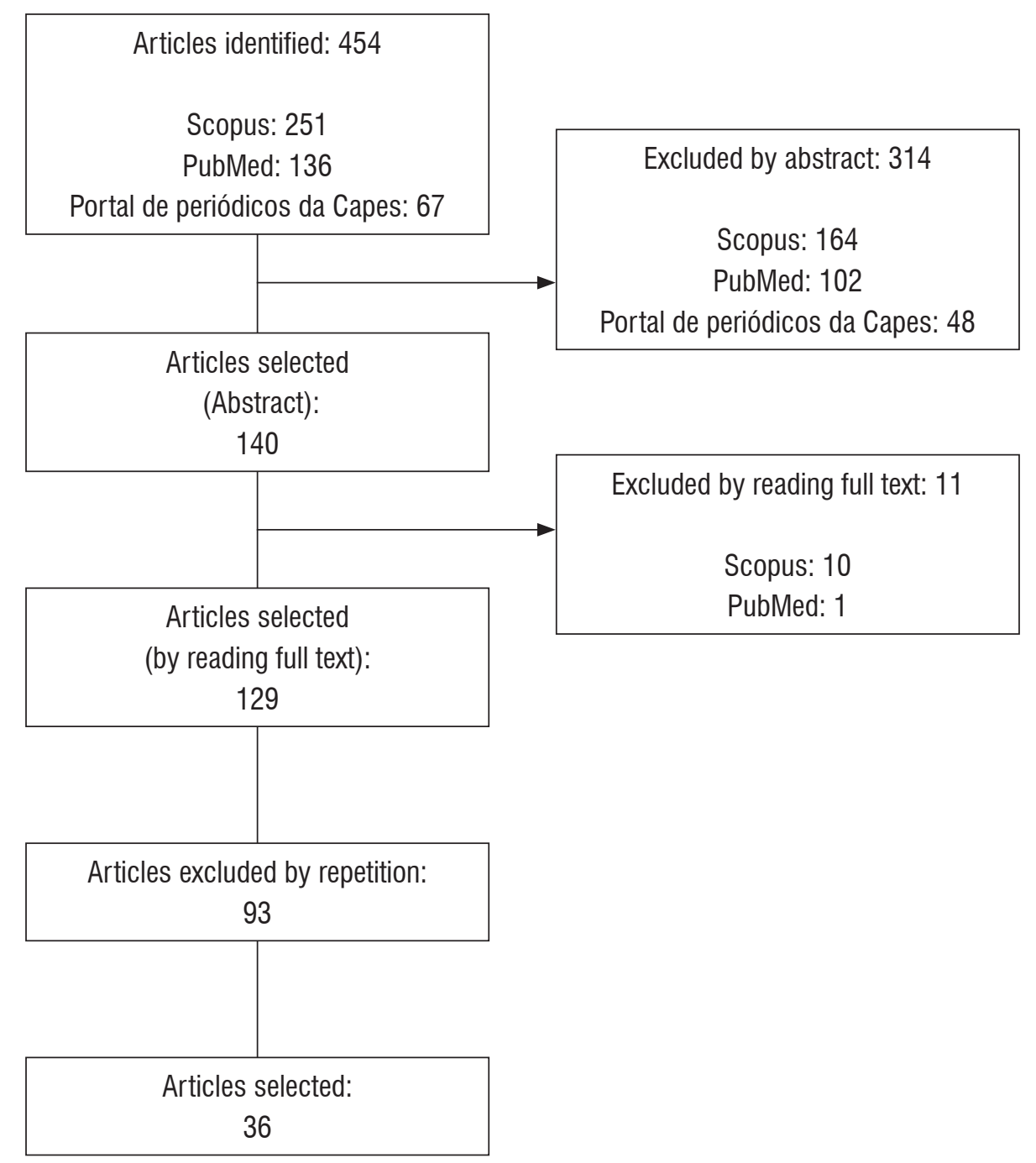

Figure 1. Flowchart showing the number of articles found and selected after applying inclusion and exclusion criterion 


\begin{tabular}{|c|c|c|c|}
\hline Author(s) & Country & Sample & Study description \\
\hline $\begin{array}{l}\text { Sanders EA, } \\
\text { Berninger VW, } \\
\text { Abbott RD } \\
(2017)^{7}\end{array}$ & United States & $\begin{array}{l}25 \text { dysgraphic children, } 60 \text { dyslexic } \\
\text { children and } 18 \text { children with oral } \\
\text { language disabilities. }\end{array}$ & $\begin{array}{l}\text { Operational memory activities associated to reading } \\
\text { and writing were tested in children with specific learning } \\
\text { disorder from 4th. ao 9th. school year. It was concluded } \\
\text { in the results that there are common difficulties among } \\
\text { groups, especially regarding language, and stimulating } \\
\text { operational memory helps learning to read and to write. }\end{array}$ \\
\hline $\begin{array}{l}\text { Schiff R, Levie } \\
\text { R }(2017)^{5}\end{array}$ & Israel & $\begin{array}{l}238 \text { readers of the Hebrew language: } 139 \\
\text { typical development and } 99 \text { dyslexics. }\end{array}$ & $\begin{array}{c}\text { The main goal was to analyze the effect of the } \\
\text { morphological knowledge about orthography in } \\
\text { schoolchildren of the Hebrew language. Orthographic } \\
\text { tasks as well as phonological awareness tasks } \\
\text { were performed. In the results, it is suggested that } \\
\text { morphological instructions help dyslexics in language } \\
\text { learning. }\end{array}$ \\
\hline $\begin{array}{l}\text { Lockiewicz M, } \\
\text { Jaskulska M } \\
(2016)^{18}\end{array}$ & Poland & $\begin{array}{c}28 \text { dyslexic students e } 28 \text { non-dyslexic } \\
\text { students. }\end{array}$ & $\begin{array}{c}\text { Specific difficulties were described in the learning } \\
\text { of English as a second language by dyslexic Polish } \\
\text { students. The results confirmed that dyslexic were less } \\
\text { fluent in reading and presentend more spelling errors of } \\
\text { phonological type. }\end{array}$ \\
\hline $\begin{array}{l}\text { Alves DC, } \\
\text { Casella EB, } \\
\text { Ferraro AA } \\
(2016)^{1}\end{array}$ & Brazil & $\begin{array}{c}32 \text { children without learning disabilities } \\
\text { (Group I), } 22 \text { dyslexic children (Group II) } \\
\text { and } 16 \text { dyslexic children with attention } \\
\text { deficit hyperactivity disorder (ADHD) } \\
\text { (Group III). }\end{array}$ & $\begin{array}{l}\text { The spelling performance of dyslexic and dyslexic } \\
\text { with ADHD schoolchildren was compared to } \\
\text { schoolchildren with no complain regarding learning. It } \\
\text { was indicated that schoolchildren from Groups II and } \\
\text { III underperformed schoolchildren from Group I and } \\
\text { intervention programs must be distinct. }\end{array}$ \\
\hline $\begin{array}{l}\text { Angelelli P et } \\
\text { al. }(2016)^{15}\end{array}$ & Italy & $\begin{array}{l}28 \text { dyslexic children: } 14 \text { dyslexic children } \\
\text { with history of oral language acquisition } \\
\text { delay and } 14 \text { dyslexic children with no } \\
\text { history of oral language acquisition delay. }\end{array}$ & $\begin{array}{c}\text { The objective was to evaluate orthography through } \\
\text { dictation. Dyslexic children with history of oral language } \\
\text { delay presented difficulties in phonological awareness, } \\
\text { making a greater number of spelling errors. Results } \\
\text { were coherent with the hypothesis that among dyslexic } \\
\text { children, those with oral language acquisition delay have } \\
\text { severe spelling deficit. }\end{array}$ \\
\hline $\begin{array}{l}\text { Daigle D et al. } \\
\quad(2016)^{8}\end{array}$ & Canada & $\begin{array}{l}32 \text { dyslexic children aged between } 11 \\
\text { years and } 4 \text { months and average reading } \\
\text { age of } 9 \text { years and } 9 \text { months were } \\
\text { compared with two groups: one group } \\
\text { of } 24 \text { readers with typical development } \\
\text { with the same average reading age } \\
\text { (9 years and } 9 \text { months) and average } \\
\text { chronological age ( } 9 \text { years and } 9 \\
\text { months) and another group composed } \\
\text { by } 24 \text { readers with typical development, } \\
\text { average chronological age (11 years and } \\
4 \text { months) and average reading age of } 12 \\
\text { years and } 1 \text { months. }\end{array}$ & $\begin{array}{l}\text { An orthographic evaluation was carried out with three } \\
\text { groups of children. Spelling errors were classified in } \\
\text { phonological, morphological, and visual-orthographic. } \\
\text { It was concluded that the spelling performance on } \\
\text { dyslexic children is the most severe in all types of } \\
\text { errors when compared to the performance of the other } \\
\text { groups. }\end{array}$ \\
\hline $\begin{array}{l}\text { Duranóvic M } \\
(2016)^{12}\end{array}$ & $\begin{array}{l}\text { Bosnia and } \\
\text { Herzegovina }\end{array}$ & 100 dyslexic children (8-14 years). & $\begin{array}{l}\text { The objective was to understand the nature of spelling } \\
\text { errors made in Bosnian language by dyslexic children. } \\
\text { It was confirmed that most of the spelling errors are of } \\
\text { phonological nature. }\end{array}$ \\
\hline $\begin{array}{l}\text { Palladino P et } \\
\text { al. }(2016)^{17}\end{array}$ & Italy & $\begin{array}{c}13 \text { dyslexic children compared to } 2 \\
\text { groups of children: } 13 \text { children of same } \\
\text { gender, age and } I Q, \text { and } 10 \text { children with } \\
\text { difficulties in learning English as a second } \\
\text { language. }\end{array}$ & $\begin{array}{c}\text { Spelling skills were investigated in the learning of English } \\
\text { as a second language by dyslexic children. Dyslexic } \\
\text { presented severe difficulty in spelling English words } \\
\text { and the most frequent errors were those related to the } \\
\text { phonological representation of words. }\end{array}$ \\
\hline
\end{tabular}




\begin{tabular}{|c|c|c|c|}
\hline Author(s) & Country & Sample & Study description \\
\hline $\begin{array}{l}\text { Ruberto N, } \\
\text { Daigle D, } \\
\text { Ammar A } \\
(2016)^{20}\end{array}$ & Canada & $\begin{array}{c}32 \text { dyslexic children were compared with } \\
\text { two groups of children: } 24 \text { children with } \\
\text { same reading level and } 25 \text { children of the } \\
\text { same age. }\end{array}$ & $\begin{array}{l}\text { The orthographic strategies used by dyslexic children } \\
\text { in dictation and spelling (sounding out letters) were } \\
\text { analyzed. The phonological strategies are the most used } \\
\text { by all groups. The orthographic/visual method explain } \\
\text { the best results of the control group. }\end{array}$ \\
\hline $\begin{array}{l}\text { Sumner E, } \\
\text { Connelly V, } \\
\text { Barnett AL } \\
(2016)^{19} \\
\end{array}$ & $\begin{array}{l}\text { United } \\
\text { Kingdom }\end{array}$ & $\begin{array}{l}31 \text { dyslexic children were compared with } \\
\text { two groups of children: } 31 \text { children of the } \\
\text { same age and } 31 \text { children of the same } \\
\text { spelling (sounding out letters) level. }\end{array}$ & $\begin{array}{l}\text { It was investigated if the spelling (sounding out } \\
\text { letters) inability, common in dyslexic, impairs written } \\
\text { production. The results point out that spelling (sounding } \\
\text { out letters) inability interferes on written performance. }\end{array}$ \\
\hline $\begin{array}{c}\text { Berget G, } \\
\text { Sandnes FE } \\
(2016)^{24}\end{array}$ & Norway & $\begin{array}{c}20 \text { dyslexic adults and } 20 \text { non-dyslexic } \\
\text { adults. }\end{array}$ & $\begin{array}{l}\text { The goal was to analyze the occurrence of spelling } \\
\text { errors made by dyslexic adults and non-dyslexic adults } \\
\text { when searching on Google. Dyslexics presented a highe } \\
\text { number of spelling errors, they also looked at the screen } \\
\text { fewer times during the research. If the autocomplete } \\
\text { suggestions were used at a higher frequency, the } \\
\text { number of spelling errors would be fewer. }\end{array}$ \\
\hline $\begin{array}{l}\text { Torrance M et } \\
\text { al. }(2016)^{33}\end{array}$ & $\begin{array}{l}\text { United } \\
\text { Kingdom }\end{array}$ & $\begin{array}{c}26 \text { dyslexic teens and } 26 \text { non-dyslexic } \\
\text { teens. }\end{array}$ & $\begin{array}{l}\text { Texts were produced using a computer keyboard: a } \\
\text { regular keyboard and a keyboard with its letters covered } \\
\text { Dyslexic made more spelling errors and wrote shorter } \\
\text { texts using the keyboard with the covered letters. }\end{array}$ \\
\hline $\begin{array}{l}\text { Tilanus EAT, } \\
\text { Segers E, } \\
\text { Verhoeven L } \\
(2016)^{29}\end{array}$ & Netherlands & $\begin{array}{l}54 \text { dyslexic children and } 61 \text { children with } \\
\text { regular development. }\end{array}$ & $\begin{array}{l}\text { Reading and spelling gains by dyslexic and non-dyslexic } \\
\text { were investigated through phonic intervention. Dyslexic } \\
\text { presented lower reading and spelling levels in the pre- } \\
\text { test. After intervention, there was some progress on } \\
\text { reading tasks and rapid automatic naming. }\end{array}$ \\
\hline $\begin{array}{l}\text { Bigozzi L, } \\
\text { Tarchi C, } \\
\text { Pinto G, } \\
\text { Gamannossi } \\
\text { BA }(2016)^{2}\end{array}$ & Italy & 407 Italian students. & $\begin{array}{l}\text { School progress of students from 1st to 3rd year of } \\
\text { elementary was tracked. Throughout the study period, } \\
\text { students were tested in phonological awareness, reading } \\
\text { and orthography. Possible students with dyslexia profile } \\
\text { were detected in their 1st year because of their reading } \\
\text { and spelling performance. It was concluded that early } \\
\text { intervention is useful to reduce schooling difficulties. }\end{array}$ \\
\hline $\begin{array}{l}\text { Suárez-Coalla } \\
\text { et al. }(2016)^{11}\end{array}$ & Spain & $\begin{array}{c}19 \text { dyslexic children and } 28 \text { non-dyslexic } \\
\text { children. }\end{array}$ & $\begin{array}{l}\text { The children performed a dictation of words with } \\
\text { different orthographic levels. In the results, dyslexic } \\
\text { children made more spelling errors (irregular words). } \\
\text { It was concluded that dyslexic children have difficulties } \\
\text { in developing adequate orthographic representations, } \\
\text { highlighting the need to exploit further strategies to } \\
\text { improve their performance regarding written language. }\end{array}$ \\
\hline $\begin{array}{c}\text { Donovan JL, } \\
\text { Marshall CR } \\
(2016)^{36}\end{array}$ & $\begin{array}{l}\text { United } \\
\text { Kingdom }\end{array}$ & $\begin{array}{c}22 \text { dyslexic children and } 44 \text { children with } \\
\text { average development. }\end{array}$ & $\begin{array}{l}\text { The main goal was to investigate the capacity of } \\
\text { dyslexic and non-dyslexic children when providing them } \\
\text { reports of strategies they use at a spelling task. In the } \\
\text { results, it is presented that dyslexic children use more } \\
\text { the phonological strategy when trying to spell the word } \\
\text { correctly and that stimulating dyslexic children to think } \\
\text { about the strategies they use to spell can be beneficial to } \\
\text { the learning of orthography. }\end{array}$ \\
\hline $\begin{array}{l}\text { Ostberg P, } \\
\text { Backlund C, } \\
\text { Lindstrom E } \\
(2016)^{25}\end{array}$ & Switzerland & $\begin{array}{l}23 \text { dyslexic adults and } 23 \text { adults that } \\
\text { belong to the control group. }\end{array}$ & $\begin{array}{l}\text { It was evaluated the applicability of a reading and writing } \\
\text { test. Dyslexic adults presented more difficulties in } \\
\text { reading and spelling tasks. }\end{array}$ \\
\hline
\end{tabular}




\begin{tabular}{|c|c|c|c|}
\hline Author(s) & Country & Sample & Study description \\
\hline $\begin{array}{l}\text { Breadmore } \\
\text { HL, Carroll JM } \\
(2016)^{28}\end{array}$ & $\begin{array}{l}\text { United } \\
\text { Kingdom }\end{array}$ & $\begin{array}{l}\text { Experiment 1: composed by } 135 \text { children } \\
\text { with average development, being } 24 \text { at } \\
\text { beginning reading level, } 47 \text { children at } \\
\text { intermediary reading level and } 64 \text { children } \\
\text { at advanced reading level. Experiment } \\
2: \text { composed by } 29 \text { children with otitis } \\
\text { media history that were asked to perform } \\
\text { the same evaluation of Experiment } 1 .\end{array}$ & $\begin{array}{l}\text { The goal was to analyze different causes of spelling } \\
\text { errors through dictation of words. In the results, different } \\
\text { causes are suggested to the spelling difficulties: dyslexic } \\
\text { children have difficulties to generalize morphologic } \\
\text { relations and children with otitis had a phonological/ } \\
\text { perceptive base difficulties. }\end{array}$ \\
\hline $\begin{array}{l}\text { Binamé F, } \\
\text { Danzio S, } \\
\text { Poncelet M } \\
(2015)^{37}\end{array}$ & Belgium & $\begin{array}{c}26 \text { dyslexic children (11 years and } 1 \\
\text { month) were compared with two groups: } \\
\text { one group of } 26 \text { readers with average } \\
\text { development and same age (11 years and } \\
1 \text { month) and a group of } 26 \text { readers with } \\
\text { average development and same reading } \\
\text { average. }\end{array}$ & $\begin{array}{l}\text { It was examined the skills dyslexic children have to } \\
\text { create new orthographic representations and to store } \\
\text { them in their long-term memory. Dyslexic children } \\
\text { learned well new orthographic forms, but presented a } \\
\text { difficulty in long-term retention. }\end{array}$ \\
\hline $\begin{array}{l}\text { Afonso 0, } \\
\text { Suárez-Coalla } \\
\text { P, Cuetos F } \\
(2015)^{23}\end{array}$ & Spain & $\begin{array}{l}20 \text { dyslexic adults and } 20 \text { adults with no } \\
\text { reading or spelling struggles. }\end{array}$ & $\begin{array}{l}\text { The objective was to investigate the spelling deficits } \\
\text { at adulthood. In the results, dyslexic presented more } \\
\text { spelling errors than their non-dyslexic peers. Difficulties } \\
\text { persisted at adulthood and they seem to be associated } \\
\text { to a deficit that affects lexical processing. }\end{array}$ \\
\hline $\begin{array}{l}\text { Rothe J et al. } \\
\qquad(2015)^{10}\end{array}$ & Germany & $\begin{array}{c}19 \text { dyslexic children and } 32 \text { children with } \\
\text { typical development. }\end{array}$ & $\begin{array}{l}\text { It was evaluated the orthographic process on dyslexic } \\
\text { children. When compared to non-dyslexic children, they } \\
\text { presented more difficulties at the lexical level with few } \\
\text { skills to recognize orthographically incorrect words. }\end{array}$ \\
\hline $\begin{array}{l}\text { Roy P et al. } \\
(2015)^{30}\end{array}$ & $\begin{array}{l}\text { United } \\
\text { Kingdom }\end{array}$ & $\begin{array}{l}68 \text { children with intense auditory } \\
\text { deficiency and } 20 \text { dyslexic children. }\end{array}$ & $\begin{array}{l}\text { The objective of the research was to verify the } \\
\text { performance of deaf children and dyslexic children } \\
\text { during dictation and reading. Most of spelling errors } \\
\text { were of phonological base to both groups, suggesting } \\
\text { the investment in phonological strategies since } \\
\text { alphabetization. }\end{array}$ \\
\hline $\begin{array}{l}\text { Re AM, } \\
\text { Cornoldi C } \\
(2015)^{31}\end{array}$ & Italy & $\begin{array}{c}22 \text { children with attention deficit } \\
\text { hyperactivity disorder (ADHD) and } 13 \\
\text { dyslexic children. }\end{array}$ & $\begin{array}{l}\text { The performance of children with ADHD and dyslexic } \\
\text { children was analyzed through copy and dictation } \\
\text { of words. The performance of the two groups was } \\
\text { distinct: dyslexic children made less spelling errors } \\
\text { when copying and ADHD children presented more } \\
\text { spelling errors during copy activity. It was suggested } \\
\text { that difficulties in dyslexic were higher on phonological } \\
\text { matters and difficulties on ADHD children are due to their } \\
\text { short attention span. }\end{array}$ \\
\hline $\begin{array}{l}\text { Berninger VW } \\
\text { et al. }(2015)^{34}\end{array}$ & United States & 35 dyslexic and disgraphic children. & $\begin{array}{c}\text { The objective was to evaluate the use of iPad in writing } \\
\text { and orthographic training activities with children with } \\
\text { specific learning disorders. In the results presented, } \\
\text { children improved significantly with the assistance of } \\
\text { technology with regards to writing speed and spelling } \\
\text { errors recognition. }\end{array}$ \\
\hline $\begin{array}{l}\text { Wang HC, } \\
\text { Nickels L, } \\
\text { Castles A } \\
(2015)^{22}\end{array}$ & Australia & 2 dyslexic children aged 10 years. & $\begin{array}{l}\text { It was investigated the relation between the phonological } \\
\text { decoding and spelling performance. In the results, it is } \\
\text { suggested that the phonological decoding skill is not the } \\
\text { only one requirement to acquire orthographic knowledge } \\
\text { of words. }\end{array}$ \\
\hline $\begin{array}{l}\text { Giannouli V, } \\
\text { Pavlidis GT } \\
(2014)^{9}\end{array}$ & Greece & $\begin{array}{l}58 \text { Greek dyslexics and } 58 \text { American } \\
\text { dyslexics. }\end{array}$ & $\begin{array}{c}\text { The types of spelling errors made by Greek and } \\
\text { American dyslexics were characterized. In the results } \\
\text { presented, the Greek dyslexics made less phonological } \\
\text { errors and more grammatical errors than American } \\
\text { dyslexics and this is due to their own linguistic } \\
\text { properties. }\end{array}$ \\
\hline
\end{tabular}




\begin{tabular}{|c|c|c|c|}
\hline Author(s) & Country & Sample & Study description \\
\hline $\begin{array}{l}\text { Tops W et al. } \\
(2014 a)^{26}\end{array}$ & Belgium & $\begin{array}{l}100 \text { dyslexic undergraduate students and } \\
100 \text { non-dyslexic undergraduate students. }\end{array}$ & $\begin{array}{l}\text { The goal was to analyze if undergraduate dyslexic } \\
\text { students are aware of their own spelling errors. It was } \\
\text { concluded that there is no evidence that dyslexics } \\
\text { make more spelling errors because they are not aware } \\
\text { of their difficulties but because of their own linguistic } \\
\text { impairment. }\end{array}$ \\
\hline $\begin{array}{l}\text { Tops W et al. } \\
(2014 b)^{27}\end{array}$ & Belgium & $\begin{array}{l}100 \text { dyslexic undergraduate students and } \\
100 \text { non-dyslexic undergraduate students. }\end{array}$ & $\begin{array}{l}\text { The objective was to compare the types of spelling } \\
\text { errors of dyslexic students and non-dyslexic. Dyslexics } \\
\text { made twice as more spelling errors than non-dyslexics. } \\
\text { The most frequent spelling errors were of phonological } \\
\text { nature. }\end{array}$ \\
\hline $\begin{array}{l}\text { Hiscox L, } \\
\text { Leonaviciute } \\
\text { E, Trevor H } \\
(2014)^{14}\end{array}$ & $\begin{array}{l}\text { United } \\
\text { Kingdom }\end{array}$ & $\begin{array}{l}22 \text { dyslexic undergraduate students and } \\
27 \text { non-dyslexic undergraduate students. }\end{array}$ & $\begin{array}{l}\text { It was investigated the relation between working } \\
\text { memory and spelling through automatic orthographic } \\
\text { corrector. It was concluded that the use of the software } \\
\text { can be beneficial to dyslexics. }\end{array}$ \\
\hline $\begin{array}{l}\text { Morken F, } \\
\text { Helland T } \\
(2013)^{38}\end{array}$ & Norway & $\begin{array}{c}13 \text { dyslexic children and } 28 \text { non-dyslexic } \\
\text { children. }\end{array}$ & $\begin{array}{l}\text { The objective was to evaluate the writing of dyslexic } \\
\text { and non-dyslexic children. In the results, it was pointed } \\
\text { out that dyslexic children spent more time to perform } \\
\text { activities and made a greater number of errors. }\end{array}$ \\
\hline $\begin{array}{c}\text { Doignon- } \\
\text { Camus N et al. } \\
(2013)^{39}\end{array}$ & France & $\begin{array}{c}27 \text { dyslexic children and } 28 \text { non-dyslexic } \\
\text { children. }\end{array}$ & $\begin{array}{l}\text { The goal was to investigate the orthographic and } \\
\text { phonological processing skills of dyslexic children. } \\
\text { It was reported that dyslexic presented efficient } \\
\text { orthographic processing skills but they are hindered due } \\
\text { to phonological inability. }\end{array}$ \\
\hline $\begin{array}{l}\text { Protopapas A } \\
\text { et al. }(2013)^{13}\end{array}$ & Greece & $\begin{array}{c}542 \text { non-dyslexic children and } 44 \text { dyslexic } \\
\text { children. }\end{array}$ & $\begin{array}{l}\text { Most common spelling errors made by Greek dyslexic } \\
\text { and non-dyslexic children were classified. It was } \\
\text { concluded that spelling errors which come from their } \\
\text { own language arbitrary relations persist on dyslexic and } \\
\text { non-dyslexic children. However, this difficulty is greater } \\
\text { for children with dyslexia. }\end{array}$ \\
\hline $\begin{array}{l}\text { Hsu JL } \\
(2013)^{35}\end{array}$ & China & $\begin{array}{l}17 \text { dyslexic children, } 21 \text { children with } \\
\text { average development and } 19 \text { children with } \\
\text { reading level of dyslexic children. }\end{array}$ & $\begin{array}{l}\text { The objective was to identify the use of abbreviation } \\
\text { of words in text messages by dyslexic children on } \\
\text { Facebook. It was noted that dyslexic Chinese children } \\
\text { prefer to use abbreviations when writing words. }\end{array}$ \\
\hline $\begin{array}{l}\text { Plisson A, } \\
\text { Daigle D, } \\
\text { Montesinos- } \\
\text { Gelet I } \\
(2013)^{21} \\
\end{array}$ & Canada & \begin{tabular}{|c|}
26 dyslexic children were compared with \\
two groups: one group of 29 children with \\
average development and same age and \\
another group of 29 children with average \\
development, same reading age. \\
\end{tabular} & $\begin{array}{l}\text { Spelling performance in dyslexic children was } \\
\text { described. In the results, it is suggested that dyslexic } \\
\text { children need more mastery in the ability to correctly } \\
\text { spell (sound out letters) words in order to increase their } \\
\text { access to orthography. }\end{array}$ \\
\hline $\begin{array}{l}\text { McCarthy } \\
\text { JH, Tiffany } \\
\text { H, Catts H } \\
(2012)^{16}\end{array}$ & United States & $\begin{array}{c}43 \text { children with language disorder were } \\
\text { compared to } 21 \text { dyslexic children and with } \\
18 \text { with language disorder and dyslexia. }\end{array}$ & $\begin{array}{l}\text { The objective was to verify the relationship between } \\
\text { reading fluency and spelling performance. Dyslexic } \\
\text { children, regardless of having oral language disorder, } \\
\text { presented low spelling performance. }\end{array}$ \\
\hline $\begin{array}{l}\text { Serrano F, } \\
\text { Delfior S } \\
(2012)^{40}\end{array}$ & Spain & $\begin{array}{c}31 \text { dyslexic children aged (11 years and } 8 \\
\text { months) were compared with two groups: } \\
\text { one of them composed by } 31 \text { children } \\
\text { with average development and aged } \\
11 \text { years and } 9 \text { months, and the other } \\
\text { group made of } 31 \text { children with average } \\
\text { development with same average reading } \\
\text { level and average age of } 9 \text { years and } 8 \\
\text { months. } \\
\end{array}$ & $\begin{array}{l}\text { It was investigated the influence of simple syllabic } \\
\text { structures: consonant-vowel (CV), two consonant } \\
\text { clusters (CCV) in the spelling performance of dyslexic } \\
\text { children. It was concluded that the spelling of words that } \\
\text { presented two consonant clusters (CCV) is more difficult } \\
\text { to dyslexic children when compared to children with no } \\
\text { schooling difficulties. }\end{array}$ \\
\hline
\end{tabular}

Figure 2. Description of selected studies. 
The data search resulted in a total of 454 articles. At PubMed, as result of the combination of terms, 136 articles were found, at Scopus database, 251 articles were found, and at Portal de Periódicos da Capes, 67 articles were found.

When taking into consideration the inclusion and exclusion benchmarks, 36 articles were analyzed in this literature review.
The distribution of the number of publications that were included in this work about "dyslexia" AND "spelling" and "dislexia AND ortografia," from 2012 to 2017 (in this last year, the period between January and April was considered) is presented in Figure 3.

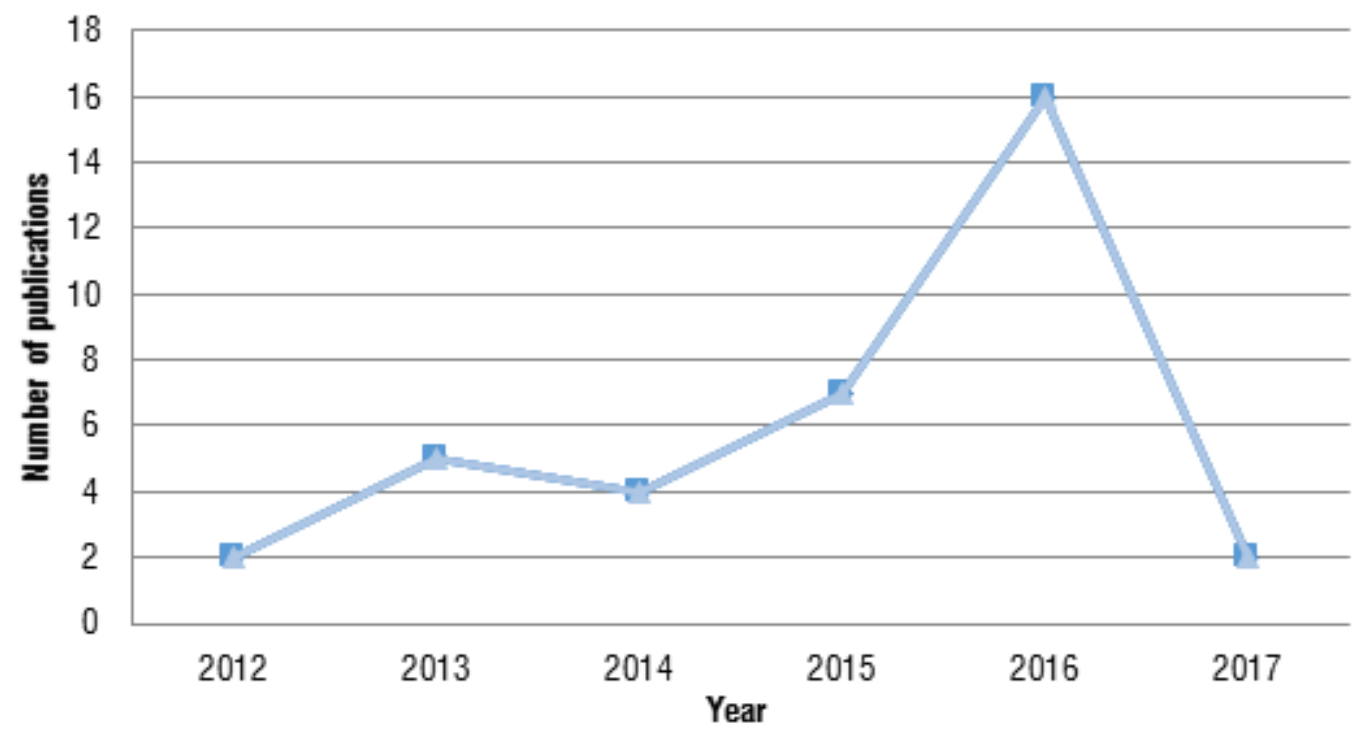

Figure 3. Distribution of the number of publications considered in this study on dyslexia and spelling and dislexia and ortografia in the period from 2012 to 2017 , by year of publication

During the search for articles stage, even with the limitation of the free terms and/or descriptors, many works that focused on reading and dyslexia were found. In order to illustrate, an additional research of the terms dyslexia AND reading, dislexia AND leitura, dyslexia AND spelling, and dislexia AND ortografia, in the last ten years, was performed using the same benchmarks disclosed in the beginning of this session. In Figure 4, it is possible to verify superiority regarding the number of publications about dyslexia and reading when compared to the number of publications about dyslexia and spelling. 


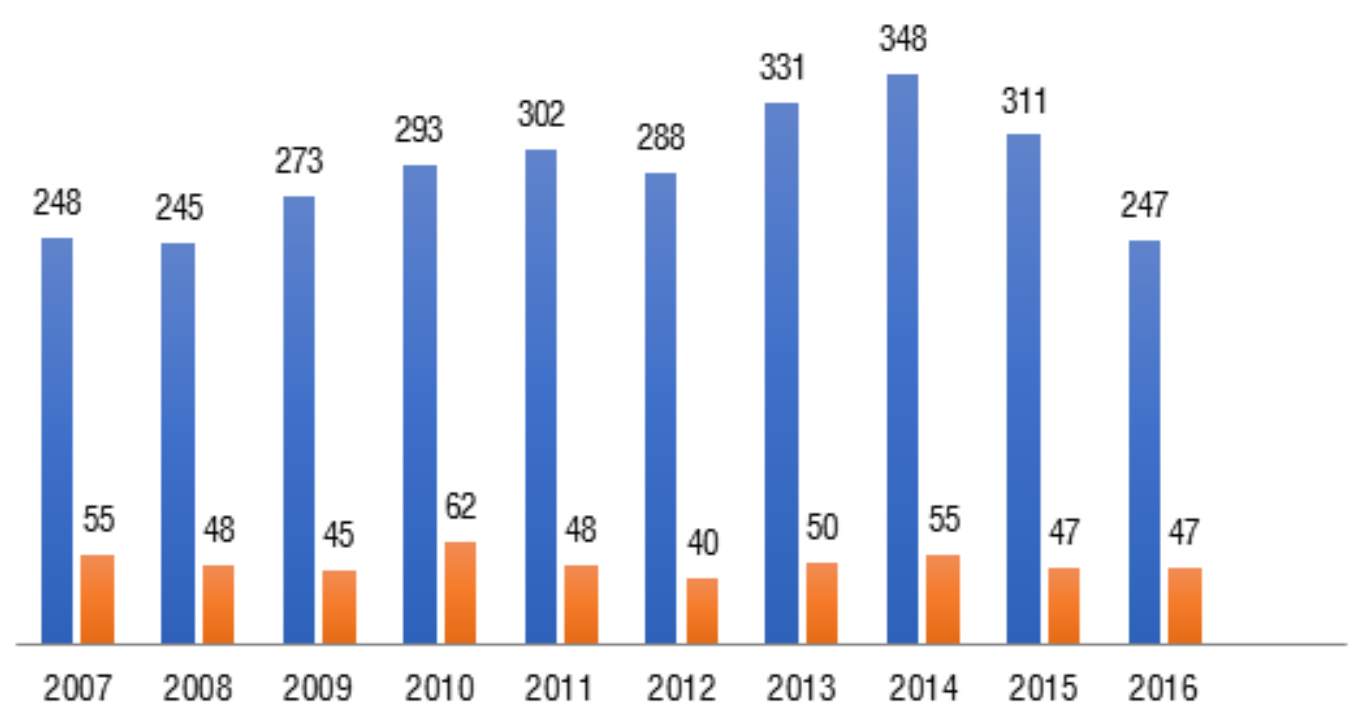

Figure 4. Distribution of the number of publications regarding the combination of dyslexia and reading and dyslexia and spelling in the last ten years

The data related to the analysis of the study selected for this review are presented in Figure 2.

Among selected articles, two publications were computed in the year 2017, sixteen in the year 2016, seven in the year 2015, four in the year 2014, five in the year 2013 and two in the year 2012. A small number of publications is observed in 2017, which is justified by the fact that the search for articles was carried out during the months of March and April 2017. The articles published in 2016 correspond to $44.44 \%$ of the selected studies. There is a growing trend in the number of publications about dyslexia and spelling, as it can be observed, for example, between the years of 2014 and 2016 in Figure 3.

In dyslexia, spelling impairments are often more extensive and persistent than in reading. This may occur due to difficulties related to the process of phonographic-orthographic conversion and its use to the correct writing of the words ${ }^{1-8}$. The analysis of the spelling errors made by children, in the educational and medical amplitude, might offer parameters for the identification of what is expected or not, assisting in the elaboration of plans and interventions according to the specificities of the difficulties ${ }^{12}$.

A study carried out with Bosnian dyslexic children ${ }^{12}$ validated the hypothesis of phonological deficit ${ }^{6}$ to explain the high frequency of errors in the writing of children with dyslexia, unlike results obtained in a
Greek-language research ${ }^{13}$, with transparent orthography (greater phoneme-grapheme regularity). Studies suggest that different language structures produce different types of errors and that in languages that have a more transparent orthography there is a smaller incidence of errors ${ }^{9}$. In Greek there is less than half the syllables when compared to English (opaque orthographic system - irregular phoneme-grapheme relation) ${ }^{13}$.

The correspondence of a phoneme to a single grapheme and vice-versa is understood as orthographic transparency. However, orthographic opacity is characterized by the irregularity to which one grapheme might correspond to several phonemes, and to which one phoneme might correspond to many graphemes. This more opacity charactheristic of the language might generate some difficulties in the learning of the written language ${ }^{2}$.

Research with Brazilian children ${ }^{1}$ analyzed the spelling performance of dyslexic children and children with dyslexia and ADHD (Attention Deficit Hyperactivity Disorder) by administering dictation of words. The authors suggest that dictation using balanced words can be useful to the formation of a lexicon database that can be used in future research.

In some researches ${ }^{1,14}$ the relationship between working memory or operational memory and spelling performance in children with dyslexia was studied. The 
writing process is complex and encompasses distinct functions that are integrated due to operational memory skills. Dyslexics present a working memory deficit that directly affects their writing tasks performance ${ }^{14}$.

The occurrence of historic of oral language disorder is common in dyslexic children ${ }^{6}$. The spelling performance was investigated in a study with Italian dyslexic children ${ }^{15}$ with and without history of delay in the acquisition of the oral language. The results presented themselves coherent with the hypothesis that dyslexic children with history of oral language disorder present more severe orthographic deficit. The relation between reading fluency and spelling performance was the focus of the investigation of an American study ${ }^{16}$ which evaluated children with language disorder, dyslexic children and children with language disorder and dyslexia. It was concluded that the history of language disorder is not the cause of low spelling performance, and children that presented the gravest orthographic disorder had a reading deficit.

Some studies investigated the acquisition of English as a second language (L2), in dyslexics ${ }^{17,18}$. The spelling performance and the most frequent types of erros were evaluated. Both studies demonstrated that the most frequent errors of dyslexics were of phonological nature.

Dyslexia is a learning disorder that affects word recognition during reading, spelling (sounding out letters) and writing. It is the result of a phonological processing deficit ${ }^{19}$. Phonological deficit hinders the learning of the alphabetical principle of the language, more specifically, the phoneme-grapheme correspondence $^{20}$. In languages such as French, this correspondence is the basic aspect for the successful learning of the reading and writing skills.

Dyslexic children are slower at spelling (sounding out letters) when compared to children with no specific learning disabilities ${ }^{19,21}$. In a study that was performed with French non-dyslexic and dyslexic children ${ }^{19}$, spelling skills were analyzed through dictation of words. The phonological strategy was common to the groups, even though it was not guaranteed that children would be able to spell all words correctly. The visual-orthographic strategy (visual memorization of words) was observed only in non-dyslexic children. Researchers pointed out the importance of using the visual-orthographic strategy in intervention programs to promote the acquisition of new words by children.

Researchers have highlighted that, beyond phonological decoding difficulties, learning to read new words is a challenge to dyslexic children, especially sight words, which are common words in English language that children deal with in written materials throughout their whole schooling process ${ }^{22}$.

Spelling difficulties have been frequently observed in dyslexic children ${ }^{1,2,7-9,20,22}$ and persist until adulthood ${ }^{14,23-27}$.

To some experts ${ }^{1,2,9,15,17}$ errors made by dyslexic schoolchildren are likely to be classified in groups. As a result of a Brazilian research ${ }^{1}$, it was presented that dyslexic schoolchildren and dyslexics with ADHD underperformed in writing when compared to children with no learning disorders. They made arbitrary spelling errors that are directly related to visual memory, knowledge of orthographic rules, lexicon and morphology.

The kind of phoneme-grapheme correspondence error depends on the phonetic/position context is a high frequency error category in dyslexic Brazilian children and dyslexic Brazilian children with ADHD'. These errors are observed in the writing of irregular words of the Portuguese language, for example: feliz by felis, dança by dansa, visual by vizual, xícara by chicara, garrafa by garafa, longe by lonje, trouxe by trousse, colégio by coléjio, faixa by faicha, macarrão by macarão, lixo by licho, among others.

Researchers have investigated the spelling performance of Spanish dyslexic children ${ }^{11}$ and pointed out that the most relevant difficulties in dyslexics are related to orthographic rules, writing of irregular words, and phoneme-grapheme conversion skill (vaso (cup) for baso, hueco (hollow) for ueco, chaqueta (jacket) for chaceta).

Errors of phonological nature were also the most frequently observed in a research with dyslexic Bosnian children ${ }^{12}$. Phonological errors are result of the substitution of letters with similar pronunciation (biti by piti, slab by slap, zima by sima).

In a study performed with dyslexic and non-dyslexic French children ${ }^{8}$, the results demonstrated that all groups of children made the non-phonological error, for example: vert (green) by verre (cup). However, in another French study ${ }^{15}$, the spelling errors in dyslexic children were classified according to their nature, being the phonological ones the most frequent, for example: quota by cuota and febbre by febre.

The kind of lack or inadequate presence of accent was frequent in dyslexic Brazilian children as well', which is expected, as it is related to orthographic rules 
that are considered complex, such as notion of syllabic division and stress of words.

In a research with dyslexic and non-dyslexic undergraduate students, it was pointed out that the occurrence of a greater number of spelling errors made by dyslexics is not due to the fact they are less aware of their difficulties, but due to their own linguistic disability ${ }^{27}$.

Research about learning disorder, in special dyslexia, have focused on the difficulties in acquisition of the correspondence between phonemegrapheme ${ }^{12,18,22,28-30}$. The phonic intervention is a way to stimulate phonological skills in advance in dyslexic children ${ }^{29}$ and on children that present early learning profile with dyslexic characteristics or other learning disabilities ${ }^{4}$.

A study ${ }^{31}$ compared the spelling performance among children with dyslexia and children with ADHD. Its outcome suggested that intervention programs be distinct due to the specificity of each group. Dyslexic children made less errors when copying as compared to children with ADHD.

Researchers $^{1}$ emphasize that interventions regarding orthography must guarantee a systematic approach in the learning of the relation phonemegrapheme, and afterwards in the learning of orthographic rules both for school children without learning disabilities and schoolchildren with learning disabilities. Researchers point to a failure in formal teaching of the aforementioned aspects.

A study performed with Dutch children ${ }^{29}$ proposed a phonic intervention program based on spelling (sounding out letters) activities associated to cards that depict images related to their phonemes. In the results presented by the study, it was observed that the intervention program improved the performance of dyslexic children regarding reading, spelling (sounding out letters) and recognizing the relation between grapheme-phoneme. Operational memory activities associated to reading and writing were suggested to be introduced in the intervention program in the spelling difficulties of dyslexic children 7 . Dyslexic Hebrews were subjected to an orthographic intervention program through activities that involved morphological analysis of words 5 .

The use of information and communication technology (ICT), such as softwares that provide orthographic auto correction, tools for evaluation of reading and comprehension of texts, and e-readers, have assisted intervention of dyslexic children ${ }^{14,25,32-36}$.
Research has tested non-dyslexic and dyslexic children while they performed orthographic tasks ${ }^{37-40}$. It was suggested that evaluation activities on dyslexic children be as diversified as possible as children usually refuse to perform formal reading and writing tasks, which is justifiable due to their own learning disabilities ${ }^{40}$.

\section{CONCLUSION}

This study addressed national and international publications about spelling in the context of dyslexia. It was observed that some studies in the literature highlight that the difficulties in the performance of the written language in dyslexic children are not exclusively due to phonological process fail, they are also secondary to alterations in the orthographic processing. Researchers suggest that beyond phonological activities, intervention strategies should address orthographic and lexical activities. Few studies analyzed the difficulties dyslexic children present to deal with new words in written material as well as to write correctly high frequency words in their mother language.

\section{ACKNOWLEDGEMENT}

To Coordenação de Aperfeiçoamento de Pessoal de Nível Superior (CAPES) for granting the first author the financial support.

\section{REFERENCES}

1. Alves DC, Casella EB, Ferraro AA. Spelling performance of students with developmental dyslexia and with developmental dyslexia associated to attention deficit disorder and hyperactivity. CoDas. 2016;28(2):123-31.

2. Bigozzi L, Christian T, Pinto G, Gamannossi BA. Predicting dyslexia in a transparente orthography from grade 1 literacy skills: a prospective Cohort study. Read Writ Q. 2016;32(1):353-72.

3. Zorzi JL. Processamento fonológico e ortográfico e suas implicações no diagnóstico dos transtornos de aprendizagem. In: Pantano T, Zorzi JL (orgs). Neurociência aplicada à aprendizagem. São José dos Campos. 2009. p. 141-55.

4. Conrad NJ, Harris N, Williams J. Individual diferences in children's literacy developmental: the contribuition of orthographic knowledge. Read Writ. 2013;26(8):1223-39. 
5. Schiff R, Levie R. Spelling and morphology in dyslexia: a developmental study across the school years. Dyslexia. 2017;23(2):1-21.

6. Lyon GR, Shaywitz SE, Shaywitz BA. Defining dyslexia, comorbidity, teacher's knowledge of language and reading. Ann Dyslexia. 2003;53(1):1-14.

7. Sanders EA, Berninger VW, Abbot RD. Sequential prediction of literacy achievement for specific learning disabilities contrasting in impaired levels of language in grade 4 to 9 . J Learn Disabil. 2017;50(1):1-21.

8. Daigle D, Costerg A, Plisson A, Ruberto N, Varin J. Spelling errors in French-speaking children with dyslexia: phonology may not provide the best evidence. Dyslexia. 2016;22(2):137-57.

9. Giannouli V, Pavlidis GT. What can spelling errors tell us about the causes and treatment of dyslexia? Nasen. Supp Learn. 2014;29(3):244-60.

10. Rothe J, Cornell S, Elena I, Schulte-Korne G. A comparison of orthograpic processing in children with and without reading and spelling disorder in a regular orthography. Read Writ. 2015;28(1):1307-32.

11. Suárez-Coalla P, Villanueva N, GonzálezPumariega S, González-Nosti M. Spelling difficulties in Spanish-speaking children with dyslexia. Infancia y Aprendizaje. 2016;39(2):275-311.

12. Duranovic, M. Spelling errors of dyslexic children in Bosnian language with transparent orthography. J Learn Disabil. 2016;49(2):1-11.

13. Protopapas A, Fakou A, Drakopoulou S, Skaloumbakas C, Mouzaki A. What do spelling errors tell us? Classification and analysis of errors made by Greek schoolchildren with and without dyslexia. Read Writ. 2013;26(5):615-46.

14. Hiscox L, Leonaviciute E, Trevor H. The effects of automatic spelling correction software on understanding and comprehension in compensated dyslexia: improved recall following dictation. Dyslexia. 2014;20(3):208-24.

15. Angelelli P, Marinelli CV, laia M, Putzolu A, Gasperini $F$, Brizzolara D et al. Spelling impairments in Italian dyslexic children with and without a history of early language delay. Are there any differences? Front Psychol. $2016 ; 7(1): 1-13$.

16. McCarthy JH, Hogan T, Catts, HW. Is weak oral language associated with poor spelling in school-age children with specific language impairment, dyslexia or both? Special Education and Communication Disorders Faculty Publications. Clin Linguist Phon. 2012;26(9):791-805.

17. Palladino P, Cismondo D, Ferrari M, Ballagamba I, Cornoldi C. L2 spelling errors in Italian children with dyslexia. Dyslexia. 2016;22(2):158-72.

18. Lockiewicz M, Jaskulska M. Difficulties of Polish students with dyslexia in reading and spelling in English as L2. Learn Individ Differ. 2016;51(1):256-64.

19. Sumner E, Connelly V, Barnett AL. The influence of spelling ability on vocabular choices when writing for children with dyslexia. J Learn Disabil. 2016;49(3):293-304.

20. Ruberto N, Daigle D, Ahlem A. The spelling strategies of Francofone dyslexics students. Read Writ. 2016;29(4):659-81.

21. Plisson A, Daigle D, Montesinos-Gelet I. The spelling skills of French-speaking dyslexic children. Dyslexia. 2013;19(2):76-91.

22. Wang HC, Nickels L, Castles A. Orthograpic learning in developmental surface and phonological dyslexia. Cognitive Neuropsych. 2015;32(2):2-22.

23. Afonso $O$, Suárez-Coalla $P$, Cuetos $F$. Spelling impairments in Spanish dyslexic adults. Front Psychol. 2015;6(1):1-10.

24. Berget G, Sandnes FE. Do autocomplete functions reduce the impact of dyslexia on informationsearching behavior? The case of google. J Assoc Inf Sci Tech. 2016;67(10):2320-8.

25. Ostberg P, Backlund C, Lindstrom E. Convergent and diagnostic validity of STAVUX, a word and pseudoword spelling test for adults. Logoped Phoniatr Vocol. 2016;41(3):124-8.

26. Tops W, Callens MD, Bijn E, Brysbaert M. Spelling in adolescentes with dyslexia: errors and models of assessment. J Learn Disabil. 2014;47(4):295-306.

27. Tops W, Callens M, Desoete A, Stevens M, Brysbaert M. Metacognition for spelling in higher education students with dyslexia: is there evidence for the dual burden hypothesis. Plos One. 2014;9(9):1-7.

28. Breadmore HL, Carroll JM. Morphological spelling in spite of phonological deficits: evidence from children with dyslexia and otitis media. Appl. Psycholinguis. 2016;37(6):1439-60.

29. Tilanus EAT, Segers E, Verhoeven L. Responsiveness to intervention in chidren with dyslexia. Dyslexia. 2016;22(3):214-32.

30. Roy P, Shergold Z, Kyle FE, Herman R. Spelling in oral deaf and hearing dyslexic children: a 
comparison of phonologically plausible erros. Res.

Dev. Disabil. 2015;36(1):277-90.

31. Re AM, Cornoldi C. Spelling errors in text copying by children with dyslexia and ADHD symptoms. J Learn Disabil. 2015;48(1):73-82.

32. Cidrim L, Madeiro F. Information and Communication Technology (ICT) applied to dyslexia: literature review. Rev CEFAC. 2017;19(1):99-108.

33. Torrance M, Ronneberg V, Johansson C, Uppstad $\mathrm{PH}$. Adolescent weak decoders writing in a shallow orthography: process and product. Sci Stud Read. 2016;20(5):375-88.

34. Berninger VW, William N, Tanimoto S, Thompson $\mathrm{R}$, Abbott RD. Computer instruction in handwriting, spelling, and composing for students with specific learning disabilities in grades 4-9. Comput Educ. 2015;81(1):154-68.

35. Hsu JL. Exploring the relationships between the use of text message language and the literacy skills of dyslexic and normal students. Res. Dev. Disabil. 2013;34(1):423-30.

36. Donovan JL, Marshall CR. Comparing the verbal self-reports of spelling strategies used by children with and without dyslexia. Int J Disabil Dev Ed. 2016;63(1):27-44.

37. Binamé F, Danzio S, Poncelet M. Relative ease in creating detailed orthographic representations contrasted with severe difficulties to maintain them in long-term memory among dyslexic children. Dyslexia. 2015;21(4):361-70.

38. Morken F, Helland T. Writing in dyslexia: product and process. Dyslexia. 2013;19(3):131-48.

39. Doignon-Camus N, Seigneuric A, Perrier E, Sisti A, Zagar D. Evidence for a preserved sensitivity to orthographic redundancy and impaired access to phonological syllables in French developmental dyslexics. Ann of Dyslexia. 2013;63(2):117-32.

40. Serrano F, Delfior S. Spanish dyslexic spelling abilities: the case of consonant clusters. J Read Res. 2012;35(2):169-82. 